Abstracta Iranica

Revue bibliographique pour le domaine irano-aryen

Volume 32-33 | 2013

Comptes rendus des publications de 2009-2010

\title{
Javier Álvarez-Món. Ashurbanipal's Feast: A View from Elam
}

\section{Rémy Boucharlat}

\section{(2) OpenEdition \\ 1 Journals}

Édition électronique

URL : http://journals.openedition.org/abstractairanica/40131

DOI : 10.4000/abstractairanica.40131

ISSN : 1961-960X

\section{Éditeur :}

CNRS (UMR 7528 Mondes iraniens et indiens), Éditions de l'IFRI

\section{Édition imprimée}

Date de publication : 1 décembre 2013

ISSN : 0240-8910

\section{Référence électronique}

Rémy Boucharlat, « Javier Álvarez-Món. Ashurbanipal's Feast: A View from Elam », Abstracta Iranica [En ligne], Volume 32-33 | 2013, document 21, mis en ligne le 01 juillet 2016, consulté le 26 septembre 2020. URL : http://journals.openedition.org/abstractairanica/40131; DOI : https://doi.org/10.4000/ abstractairanica.40131

Ce document a été généré automatiquement le 26 septembre 2020.

Tous droits réservés 


\title{
Javier Álvarez-Món. Ashurbanipal's Feast: A View from Elam
}

\author{
Rémy Boucharlat
}

\section{RÉFÉRENCE}

« Ashurbanipal's Feast: A View from Elam ». Iranica Antiqua, 45, 2009, p. 131-180, 24 fig.

L'A. revient sur un bas-relief de Ninive trouvé par Loftus au milieu du XIX s. : la représentation de l'Assyrien Assurbanipal à demi allongé sur un lit et levant une coupe ; une reine assise et levant également une coupe lui fait face. Le relief est célèbre, pour plusieurs raisons : le thème est inhabituel, scène de pique-nique royal ou scène religieuse ; éléments élamites, entre autres, dans le vêtement de la reine et ceux des quatre autres personnages, et traces évidences de martelage des deux visages. Après une période d'alliance, les Elamites se rangèrent du côté des rebelles au roi assyrien, et furent battus, d'où la représentation de leurs chefs en situation de serviteurs ou de vaincus sur différents reliefs du palais. Le martelage des visages serait l'acte iconoclaste des vainqueurs sur les Assyriens, dont des Elamites, lors de la prise de Ninive en 612. Un des spécialistes actuels de l'art élamite, l'A. donne ici les clés élamites pour l'interprétation du relief.

\section{AUTEURS}

RÉMY BOUCHARLAT

CNRS, Lyon 